\title{
HABITAT CONDITIONS OF CANADIAN GOLDENROD IN A SELECTED REGION OF EASTERN POLAND
}

\author{
Aleksandra Bielecka ${ }^{1}$, Elżbieta Królak ${ }^{1 *}$, Elżbieta Biardzka ${ }^{1}$ \\ 1 Department of Environmental Research and Life Sciences, Institute of Biology, University of Environmental \\ and Human Sciences in Siedlce, Prusa St. 12, 08-110 Siedlce, Poland \\ * Corresponding author's e-mail: kruell@o2.pl
}

Received: 2017.05.15

Accepted: 2017.06.01

Published: 2017.07.01

\begin{abstract}
The Canadian goldenrod Solidago canadensis (L) is an invasive species in Poland. It occurs both in habitats only weakly impacted by anthropogenic factors as well as in habitats subjected to intensive transformations by humans. The aim of this study was to characterise the habitats of $S$. canadensis in Mińsk Mazowiecki and in out-of-town areas. It has been shown, based on an analysis of the principal soil properties, that the sites where $S$. canadensis was found had clayey-sandy soil and a $\mathrm{C} / \mathrm{N}$ ratio indicative of medium and high soil degradation. Canadian goldenrod was found at sites with a diverse content of phosphorus, calcium and magnesium in soil, as well as a diverse soil $\mathrm{pH}$, indicative of a strongly acidic, acidic and alkaline character of the soil.
\end{abstract}

Keywords: soil, acidity, organic carbon, total nitrogen, total phosphorus, magnesium, calcium

\section{INTRODUCTION}

Solidago spp. are among the invasive plants which have been colonising an increasing number of sites in Poland [Tokarska-Guzik et al. 2012]. In natural and semi-natural populations in Poland, this genus is represented by four species: Solidago gigantea Aiton (giant goldenrod), Solidago canadensis (L.) (Canadian goldenrod), Solidago graminifolia (L.) Elliott. (grass-leaved goldenrod) and Solidago virgaurea L. (European goldenrod) [Rostański 1997]. Of these, only European goldenrod is native to Europe. The other species were brought to Europe from North America in the 18th century [Guzikowa and Maycock 1986]. Solidago spp. show a great tendency for expansion. According to literature reports [Korniak et al. 2012, Szymura and Wolski 2006], giant goldenrod and Canadian goldenrod are found in Poland relatively frequently. S. canadensis is common in the north-east of Poland [Korniak et al. 2012]. The expansion of $S$. canadensis can be attributed to the fact that it produces large numbers of seeds. An individual shoot of these spe- cies produces up to 10,000 seeds, which are easily carried by the wind for long distances [Gassman and Weber 2005]. S. canadensis is characterised by the greatest germination potential of all Solidago spp. [Szymura 2012]. The species has an allelopathic effect on the plants growing at the same sites, which eliminates competitive vegetation [Abhilasha et. al. 2008, Sun et al. 2006, Yuan et al. 2013]. It is also relatively resistant to herbicides [Rzymowska et al. 2015] and colonises habitats in urban areas [Korniak et al. 2012]. It is also found on arable land [Pużyńska et al. 2012], as well as on fallow land [Rola and Rola 2010], industrial dumping grounds [Rostański 2006] and municipal waste dumpsites [Dyguś et al. 2012]. It tolerates high concentrations of heavy metals in soil [Nowińska et al. 2012, Yang et al. 2008], which is demonstrated by the presence of this species at sites near emitters of pollution [Rostański 1997]. It has been emphasised in literature reports [Pużyńska et al. 2012] that the plant has great tolerance of chemical properties of the ground, such as the soil $\mathrm{pH}$ and the content of minerals and organic matter. Despite numerous studies of 
the invasion of $S$. canadensis [e.g. Lu et al. 2007, Moron et al. 2009, Priede 2008], there have been scarce reports on the chemical composition of the soil colonised by the species.

The aim of this study was to characterise the habitats of $S$. canadensis in Mińsk Mazowiecki and in out-of-town areas.

\section{MATERIAL AND METHODS}

The study was conducted in Mińsk Mazowiecki $\left(52.18^{\circ} \mathrm{N}, 21.56^{\circ} \mathrm{E}\right.$, province of Mazovia) and near the town, within $5 \mathrm{~km}$ of its borders. Sites were selected for the study where Solidago canadensis was found on an area of at least ca. $100 \mathrm{~m}^{2}$. The plants were identified using the description provided in the identification key for vascular plants [Rutkowski 2012]. In total, 16 sites were selected for the study: sites 1-8 were situated within the town, sites 9-16 were situated outside it. Soil samples for the study were collected in September 2016 with a sampling stick from a depth of $20 \mathrm{~cm}$. Five samples were taken at each site; they were transferred to a plastic bag and thoroughly mixed. Subsequently, the soil samples were dried and sifted through a $2 \mathrm{~mm}$ mesh sieve.

Granulometric distribution in the soil samples was determined by Bouyoucose's areometric method, as modified by Casagrande and Prószyński [Ostrowska et al. 1991]. Granulometric subgroups were identified based on the percentage of the sand, clay and silt fraction in the soil, in accordance with the classification of soils and mineral formations, adopted by the Polish Soil Science Association - PTG 2008 [Particle size...].

The following were determined in subsamples of soil homogenised in an agate mortar: organic carbon by the Tiurin method [Ostrowska et al. 1991], total nitrogen by the indophenol meth- od and total phosphorus by the molybdate method [Marczenko 1979]. Soil samples for determination of nitrogen and phosphorus were mineralised in Kjeldahl flasks in $95 \% \mathrm{H}_{2} \mathrm{SO}_{4}$ and $30 \% \mathrm{H}_{2} \mathrm{O}_{2}$ $(3: 1, \mathrm{v} / \mathrm{v})$. Additionally, the soil $\mathrm{pH}$ was determined in $1 \mathrm{M} \mathrm{KCl}$ [Ostrowska et al. 1991] and calcium and magnesium content by AAS. Calcium and magnesium determination was preceded by mineralisation of the samples in a microwave mineraliser in $\mathrm{HNO}_{3}$ and $30 \% \mathrm{H}_{2} \mathrm{O}_{2}(3: 1, \mathrm{v} / \mathrm{v})$.

The results were worked out statistically. The normality of data was tested using the ShapiroWilk test. A non-parametric Mann-Whitney U test $(p<0.05)$ was used to analyse the differences in the indexes determined for the soil samples collected within the town and outside it. The significance of correlations between the values of parameters was assessed by Spearman rank correlations. A dendrological analysis was carried out in order to compare the soil properties at different sites. The statistical analyses were performed using Statistica software (ver.12).

\section{RESULTS}

The sand fraction percentage in the soil under study varied from $62 \%$ to $86 \%$, the clay fraction varied from $7 \%$ to $32 \%$ and the silt fraction varied from $7 \%$ to $10 \%$. The granulometric composition of the soil was used to identify ten samples of sandy loam, four samples of loamy sand and two samples of light loam.

The soil $\mathrm{pH}$ ranged from 3.90 to 7.54 (Table 1). The $\mathrm{pH}$ was acidic and strongly acidic in half of the samples. The soil $\mathrm{pH}$ was higher than 7 in six samples. The $\mathrm{pH}$ values were higher in the samples collected within the town borders than in the rural areas $(Z=2.36, p=0.018)$.

The content of organic carbon did not exceed $2 \%$ in the majority of the samples. The differences

Table 1. Results of selected chemical parameters in soil samples at Solidago canadaensis (L.) located in town areas and out-of-town areas

\begin{tabular}{|c|c|c|c|c|c|c|c|}
\hline \multirow{2}{*}{ Parameter } & \multirow{2}{*}{ Unit } & \multicolumn{3}{|c|}{ Town areas } & \multicolumn{3}{c|}{ Out-of-town areas } \\
\cline { 3 - 8 } & & Mean \pm SD & Median & Range & Mean \pm SD & Median & Range \\
\hline $\mathrm{pH}$ & & & & $4.79-7.54^{\mathrm{a}}$ & & & $3.90-7.48^{\mathrm{b}}$ \\
\hline $\mathrm{Corg}$ & \multirow{2}{*}{$\mathrm{N}$} & $1.63 \pm 1.04$ & 1.24 & $0.79-3.54$ & $1.16 \pm 0.36$ & 1.01 & $0.89-1.84$ \\
\hline $\mathrm{N}$ & \multirow{2}{*}{$\mathrm{g} / \mathrm{kg}$} & $0.72 \pm 0.32$ & 0.62 & $0.38-1.32$ & $0.67 \pm 0.25$ & 0.59 & $0.4-1.16$ \\
\cline { 3 - 8 } & & $0.46 \pm 0.45$ & 0.31 & $0.21-1.56$ & $0.37 \pm 0.09$ & 0.37 & $0.25-0.49$ \\
\hline \multicolumn{2}{|c|}{$\mathrm{P} / \mathrm{N}$} & $21.6 \pm 4.52$ & 22.2 & $15.5-30.9$ & $20.8 \pm 9.44$ & 17.4 & $14.2-42.8$ \\
\hline $\mathrm{Ca}$ & \multirow{2}{*}{$\mathrm{g} / \mathrm{kg}$} & $4.96 \pm 3.97$ & 3.18 & $1.90-13.5$ & $3.65 \pm 3.40$ & 2.57 & $0.80-10.2$ \\
\cline { 3 - 8 } & & $1.31 \pm 0.55$ & 1.26 & $0.33-2.23$ & $1.06 \pm 0.53$ & 0.93 & $0.47-2.13$ \\
\hline
\end{tabular}


between the content of organic carbon in the samples collected within the town borders and outside it were not statistically significant. The nitrogen content in the soil at the selected sites varied within the following range: $0.38-1.32 \mathrm{~g} / \mathrm{kg}$. It was below $1 \mathrm{~g} / \mathrm{kg}$ in most of the samples. The content of phosphorus at the sites under study ranged from $0.21 \mathrm{~g} /$ $\mathrm{kg}$ to $1.56 \mathrm{~g} / \mathrm{kg}$. It was below $0.5 \mathrm{~g} / \mathrm{kg}$ in ca. $90 \%$ of the samples. The highest content of organic carbon, nitrogen and phosphorus was determined in a sample collected at the waste dumpsite situated in the vicinity of the wastewater treatment plant in Mińsk Mazowiecki. Like in the indexes mentioned above, no significant differences were found in the assay results for magnesium or cal- cium in soil samples collected within the town borders or outside it. The content of calcium did not exceed $4 \mathrm{~g} / \mathrm{kg}$ in most of the samples it ranged from 0.8 to $13.5 \mathrm{~g} / \mathrm{kg}$. The content of magnesium also varied within a relatively broad range between 0.33 and $2.23 \mathrm{~g} / \mathrm{kg}$ (Table 1, Fig. 1).

The content of organic carbon and total nitrogen were used to calculate the $\mathrm{C} / \mathrm{N}$ ratio. For most samples, it ranged between 18 and 30. It was above 30 in two samples. One of the samples was collected at the waste dumpsite situated in the vicinity of the wastewater treatment plant in Mińsk Mazowiecki and the other at an out-of-town site (Table 1, Fig. 1). No statistically significant differences were found for the $\mathrm{C} / \mathrm{N}$ ratio in samples

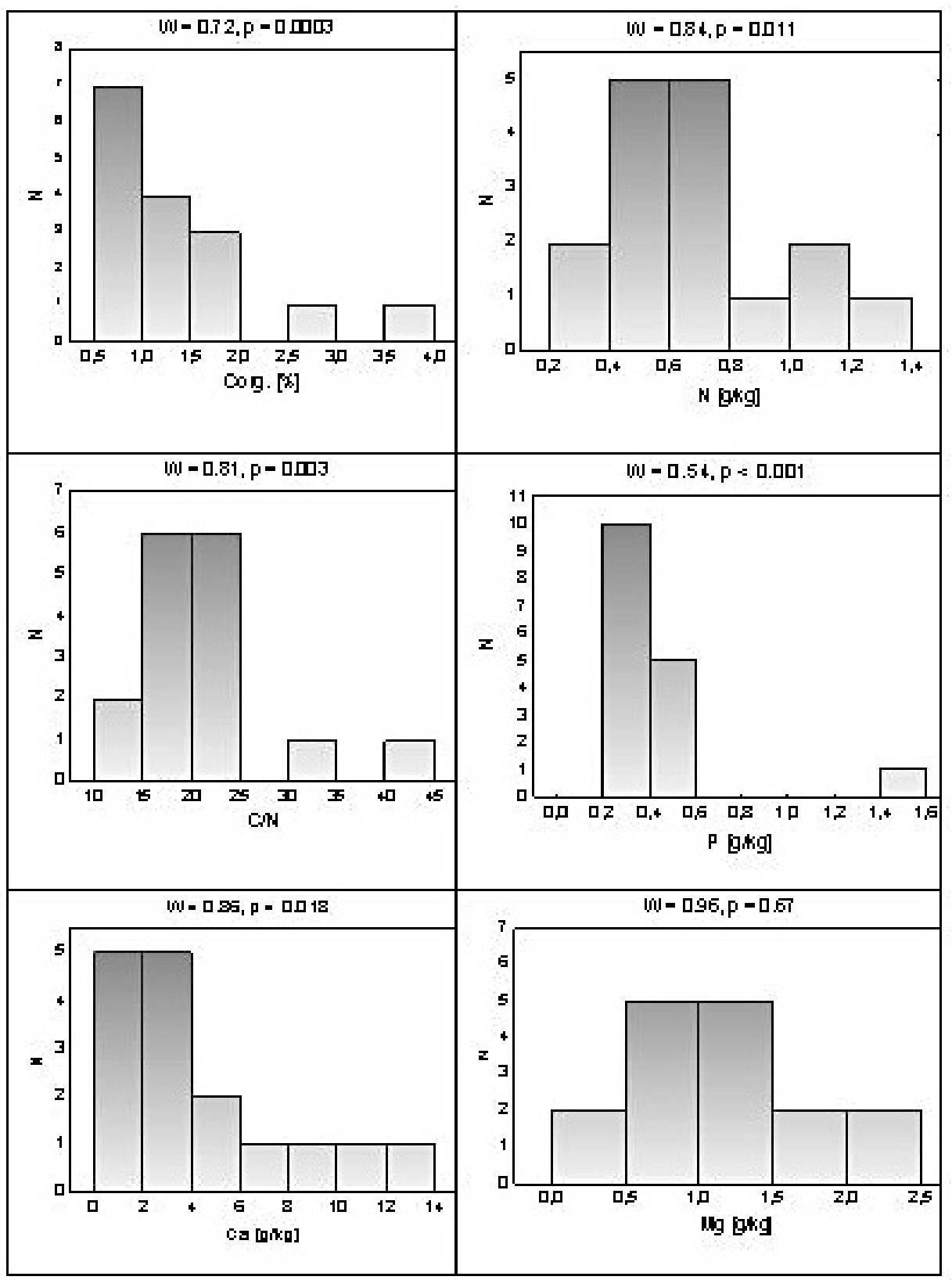

Fig. 1. Number of soil samples with different ranges of measured chemical parameters 
collected within the town borders and outside it. Statistically significant correlations were found between the soil $\mathrm{pH}$ and the calcium content $\left(\mathrm{R}_{\mathrm{s}}\right.$ $=0.51)$ and magnesium content $\left(\mathrm{R}_{\mathrm{s}}=0.64\right)$ and between $\mathrm{C}_{\text {org }}$ and nitrogen content $\left(\mathrm{R}_{\mathrm{s}}=0.84\right)$ and phosphorus content $\left(\mathrm{R}_{\mathrm{s}}=0.61\right)$.

A dendrological analysis showed a particular similarity of soil at the sites: 1, 10, 11, 15 (Fig. 2). Samples collected at these sites had a relatively low $\mathrm{C} / \mathrm{N}$ ratio, close to 15 , a low $\mathrm{pH}(<5)$, an organic carbon content of about $1 \%$ and below $1 \%$, a relatively low content of $\mathrm{P}$ (from 0.21 to $0.40 \mathrm{~g} / \mathrm{kg}$ ) and nitrogen content from 0.54 to $0.8 \mathrm{~g} / \mathrm{kg}$. Samples collected at sites 3,16 and 2 differed from majority of the other samples. Compared to the other samples, those collected at sites 3 and 16 had a high $\mathrm{C} / \mathrm{N}$ ratio: 30.1 and 42.8 , respectively, similar $\mathrm{pH}$ : 6.92 and 6.53 and a relatively high content of calcium (13.5 and $10.2 \mathrm{~g} / \mathrm{kg} /$ respectively). Sample no. 3 contained a higher concentration of nitrogen $(1.32 \mathrm{~g} / \mathrm{kg})$ and phosphorus $(1.57 \mathrm{~g} / \mathrm{kg})$ than any other sample. Sample no. 2 contained a relatively high concentration of nitrogen $(1.18 \mathrm{~g} / \mathrm{kg})$ and carbon $(2.99 \%)$ and its $\mathrm{pH}$ was high: 7.24 .

\section{DISCUSSION}

An analysis of soil samples collected at the sites colonised by $S$. canadensis showed that the chemical properties of the soil vary. These findings confirmed the literature reports [Pużyńska et al. 2012, Szymura and Szymura 2013], according to which Solidago sp., including $S$. canadensis as an invasive species, colonise soils with a broad range of $\mathrm{pH}$ values, including - as has been shown in studies - acidic and strongly acidic soils. Along with the soil $\mathrm{pH}$, the extent of soil degradation is shown by the $\mathrm{C} / \mathrm{N}$ ratio in the humus horizon. The lower it is, the less degraded the soil is [Siuta 2000]. According to Baran and Turski (1996), a $\mathrm{C} / \mathrm{N}$ ratio within a range between 8 and 10 is typical of non-degraded soils, $11-17$ - is typical of slightly degraded soils, 18-30 - soils with medium degradation degree and 30-45- highly degraded soils. It is noteworthy that the $\mathrm{C} / \mathrm{N}$ ratio was higher than 10 at all the sites where $S$. canadensis was found. The $\mathrm{C} / \mathrm{N}$ ratio determined in ca. $70 \%$ of the samples under study was indicative of medium and high degradation of the soils at the sites. Likewise, a $\mathrm{C} / \mathrm{N}$ ratio within a broad range in the surface layer of the soils where Solidago spp. were found was determined by Pużyńska et al. (2012). An increased $\mathrm{C} / \mathrm{N}$ ratio in soil at sites colonised by Solidago gigantea was also determined by Vanderhoeven et al. (2006). Results of the monitoring of arable land in Poland have shown that the average $\mathrm{C} / \mathrm{N}$ ratio in such soils is 10.4 (7.4-17.4), phosphorus content $-0.57 \mathrm{~g} / \mathrm{kg}(0.22-1.4 \mathrm{~g} / \mathrm{kg})$, calcium content $-2.8 \mathrm{~g} / \mathrm{kg}(0.2-212.9 \mathrm{~g} / \mathrm{kg})$ and magnesium content $-1.4 \mathrm{~g} / \mathrm{kg}(0.2-9.1 \mathrm{~g} / \mathrm{kg})$ [www.gios.gov. $\mathrm{pl} /$ chemizm_gleb]. A comparison of these data with the findings of this study indicate that colo-

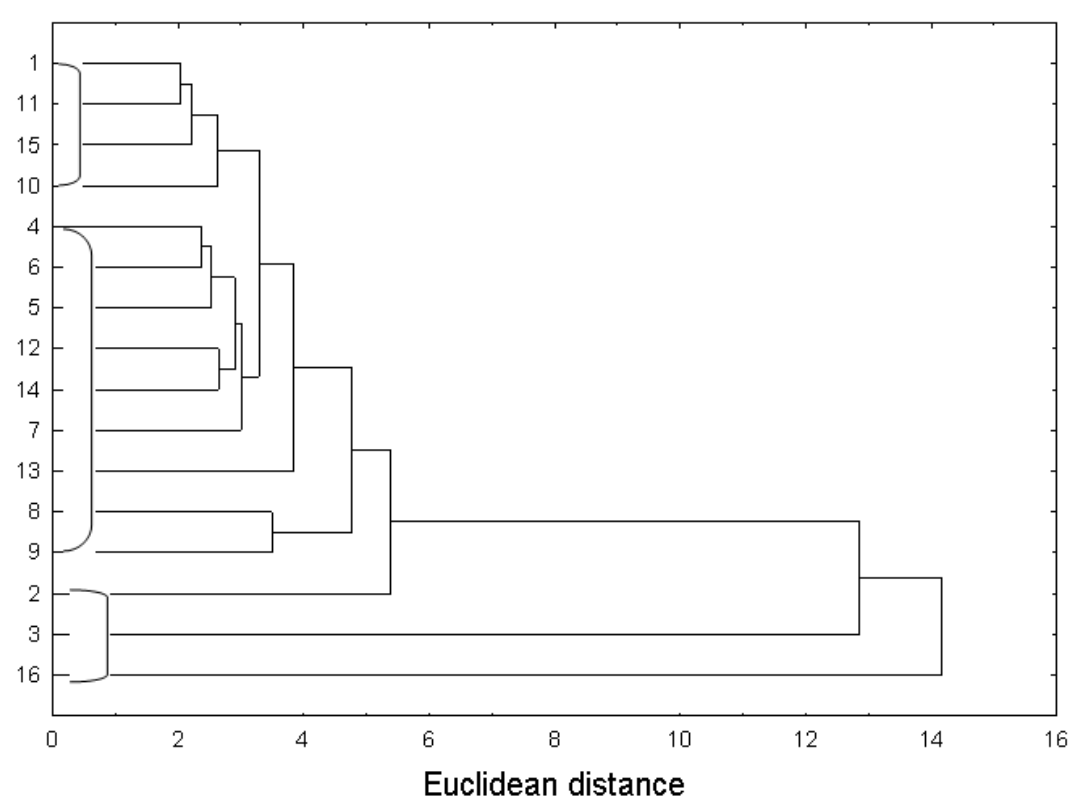

Fig. 2. Dendrogram representing groups of soil samples determined by using cluster analysis 
nisation by $S$. canadensis may result in soil degradation. It has been emphasised in the literature [Zhang et al. 2009] that S. canadensis can modify the properties of an ecosystem strongly, including selected soil characteristics. Zhang et al. (2009) pointed out that the presence of $S$. canadensis contributes to a decrease in the content of nitrogen and phosphorus in soil and to an increase in $\mathrm{C}_{\text {org }}$ and in soil $\mathrm{pH}$. According to literature reports [Jezierska-Domaradzka and Domaradzki 2012], biomass of $S$. candensis can reach up to $3.3 \mathrm{t} \mathrm{d.m./}$ ha. Because of the biomass amount, it can contribute to a significant decrease in the content of nitrogen and phosphorus in soil, thereby causing soil degradation. This seems important if a plant is used as an energy crop [Nowińska et. al 2012] and macro- and micronutrients are regularly removed from the soil with the plant biomass.

According to study findings, S. canadensis grows mainly on sandy loam. Possibly, the soil conditions, with the soil containing more than ten percent of small-grain fractions of soil (clay and silt), make it easier for the light seeds of the plant to settle and germinate. On the one hand, smallgrain fractions of soil protect seeds against being blown away from the soil and, on the other, they can supply the germinated seeds with elements necessary for their further growth.

Colonisation of increasing areas in Poland by Solidago sp., including $S$. canadensis, especially in areas which are not used for agriculture, estimated by Korniak et al. (2012) at as much as $5,000 \mathrm{~m}^{2}$ at one habitat, can pose a significant threat to biological diversity. The ease of carrying seeds long distances [Gassman and Weber 2005], high germinating potential of seeds [Szymura 2012], easy reproduction by rhizomes [SudnikWójcikowska 2011] - all this makes it necessary to take action to stem the expansion of the species.

The findings of this study have broadened and supplemented previous knowledge on the habitat conditions of Solidago canadensis. Due to the invasive character of the plant and the fact that it occupies an increasingly large area, it has been noted [Lu et al. 2007, Moron et al. 2009] that suitable programmes must be implemented to stop its expansion. According to the study findings, $S$. canadensis shows no preferences regarding the chemical characteristics of the habitats that it colonises. Therefore, actions involving changes of chemical characteristics of soils do not seem to be effective in stopping the expansion of Canadian goldenrod.

\section{CONCLUSIONS}

S. canadensis readily colonises sites with sandy-loamy soil, with $\mathrm{pH}$ within a broad range, from strongly acidic to alkaline, it grows at sites where the $\mathrm{C} / \mathrm{N}$ ratio in the soil is indicative of medium or high soil degradation. Canadian goldenrod does not show any significant preferences regarding the choice of habitats within a town or out-of-town areas.

\section{REFERENCES}

1. Abhilasha D., Quintana N., Vivanco J., Joshi J. 2008. Do allelopathic compounds in invasive Solidago canadensis s.l. restrain the native European flora? Journal of Ecology, 96, 993-1001.

2. Baran S., Turski R. 1996. Degradation of protection and recultivation of soil. Wyd. Akademii Rolniczej w Lublinie (in Polish).

3. Dyguś K.H., Siuta J., Wasiak G., Madej M. 2012. Vegetation of communal and industrial landfills. Monografia. Wyd. Wyższa Szkoła Ekologii i Zarządzania w Warszawie. 1-134 (in Polish).

4. Gassman A., Weber E. 2005. Solidago canadensis. In: Wittenberg, R.(ed.). An Inventory of Alien Species and Their Threat to Biodiversity and Economy in Switzerland. CABI Bioscience Switzerland Centre report to the Swiss Agency for Environment, Forests and Landscape (pp. 413-414). Delemont.

5. Guzikowa M, Maycock P.F. 1986. The invasion and expansion of three North American species of goldenrod (Solidago canadensis L. sensu lato, S. gigantea Ait. and S. graminifolia (L.) Salisb.) in Poland. Acta Societatis Botanicorum Poloniae, 55, 367-384.

6. Jezierska-Domaradzka A., Domaradzki K. 2012. Solidago canadensis L. as a potential energy plant - the risk to the environment and the estimation of natural raw material resources in the chosen fallow fields in Wołów County (lower Silesia). Zeszyty Naukowe Uniwersytetu Przyrodniczego we Wrocławiu, Rolnictwo C, 584, 43-52 (in Polish).

7. Korniak T., Hołodyński Cz., Wąsowicz K., Święczkowska J. 2012. American species of the genus Solidago in north-eastern Poland. Zeszyty Naukowe Uniwersytetu Przyrodniczego we Wrocławiu, Rolnictwo C, 584, 81-88 (in Polish).

8. Lu J.Z., Weng E.S., Wu X.W., Weber E., Zhao B., Li B. 2007. Potential distribution of Solidago canadensis in China. Acta Phytotaxonomica Sinica, $45,670-674$.

9. Marczenko Z. 1979. Spectrophotometric determination of the elements. PWN, Warszawa (in Polish). 
10. Moron D., Lenda M., Skórka P., Szentgyörgyi H., Settele J., Woyciechowski M. 2009. Wild pollinator communities are negatively affected by invasion of alien goldenrods in grassland landscapes. Biological Conservation, 142, 1322-1332.

11. Nowińska K., Kokowska-Pawłowska M., Patrzałek A. 2012. Metals in Calamagrostis epigejos and Solidago sp. from reclaimed post-industrial wastelands. Ekologia Terenów Wiejskich, Nr 3/III, Polska Akademia Nauk, Oddział w Krakowie, pp. 91-100 (in Polish).

12. Ostrowska A., Gawliński S., Szczubiałka Z. 1991. Methods of analysis and evaluation of soil and plant properties. Katalog, Instytut Ochrony Środowiska, Warszawa (in Polish).

13. Particle size distribution and textural classes of soils and mineral materials - classification of Polish Society of Soil Science 2008. Roczniki Gleboznawcze 2009, t. LX (2): 5-16. (in Polish).

14. Pużyńska K., Stokłosa A., Stupnicka-Rodzynkiewicz E. 2012. The impact of ecological conditions on Solidago sp. occurrence. Zeszyty Naukowe Uniwersytetu Przyrodniczego we Wrocławiu, Rolnictwo C, 584, 89-98 (in Polish).

15. Priede A. 2008. Invasive non-native Solidago species in Latvia: expansion history and current distribution. Proceedings of the Latvian Academy of Sciences, Sectio B, 62, 78-83.

16. Rola J., Rola H. 2010. Solidago spp. as bioindicator of fallow occurence on arable area. Fragmenta Agronomica, 27(3), 122-131 (in Polish).

17. Rostański A. 1997. The content of heavy metals in soil and plants from the surroundings of some emitter pollutants in Upper Silesia. Archiwum Ochrony Środowiska, 23(3/4), 181-189 (in Polish).

18. Rostański A. 2006. Spontaneous plant cover on colliery spoil heaps in Upper Silesia. Prace Naukowe Uniwersytetu Śląskiego w Katowicach, 2410, 1-232 (in Polish).

19. Rutkowski L. 2012. The key to identification of vascular plants in lowland Poland. Wydawnictwo Naukowe PWN (in Polish).

20. Rzymowska Z., Skrzyczyńska J., Wyrzykowska M. 2015. Assessment of selected herbicides applied to suppress Solidago canadensis L. Zeszyty Naukowe UPH w Siedlcach, Seria Rolnictwo, 2(2), 15-24 (in Polish).

21. Siuta J. 2000. Basis of biodegradation of petroleum derivatives of soils and wastes. Inżynieria Ekologiczna nr 2. Landfill, waste and wastewater tech- nologies. Materials from the Scientific Conference. Wysowa Zdrój, wrzesień 2000. Polskie Towarzystwo Inżynierii Ekologicznej, 23-34. (in Polish).

22. Sudnik-Wójcikowska B. 2011. Synanthropic plants, Flora of Poland. Multico Oficyna Wydawnicza, Warszawa (in Polish).

23. Sun B.J., Tan J.Z., Wan Z.G., Gu F.G., Zhu M.D., 2006. Allelopathic effects of exstracts from Solidago canadensis L. against seed germination and seedling growth of some plants. Journal Environmental Science, 18 (2), 304-309.

24. Szymura M., Wolski K. 2006. Landscape transformation in the influence of expansive North Americans perennial from Solidago L. genus. Regionalne Studia Ekologiczno-Krajobrazowe, Problemy Ekologii Krajobrazu, 16(1), 451-460 (in Polish).

25. Szymura M. 2012. Evaluation of ability for generative and vegetative reproduction of goldenrods occurred in Poland. Zeszyty Naukowe Uniwersytetu Przyrodniczego we Wrocławiu, Rolnictwo CI, 585, 103-112 (in Polish).

26. Szymura M., Szymura T.H. 2013. Soil preferences and morphological diversity of goldenrods (Solidago L.) from south-western Poland. Acta Societatis Botanicorum Poloniae. 82(2), 107-115.

27. Tokarska-Guzik B., Dajdok Z., Zając M., Zając A., Urbisz A., Danielewicz W., Hołdyński Cz. 2012. Plants of foreign origin in Poland with particular emphasis on invasive species. Wyd. Generalna Dyrekcja Ochrony Środowiska, Warszawa (in Polish).

28. Yang R.Y., Yu G.D., Tang J.J., Chen X. 2008. Effects of metal lead on growth and mycorrhizae of an invasive plant species (Solidago canadensis L.). Journal Environmental Science, 20, 739-744.

29. Yuan Y., Wang B., Zhang S., Tang J., Tu C., Hu S., Yong J.W.H., Chen X. 2013. Enhanced allelopathy and competitive ability of invasive plant Solidago canadensis in its introduced range Journal of Plant Ecology, 6(3), 253-263.

30. Vanderhoeven S., Dassonville N., Chapuis-Lardy L., Hayez M., Meerts P. 2006. Impact of the invasive alien plant Solidago gigantea on primary productivity, plant nutrient content and soil mineral nutrient concentrations.Plant and Soil, 286, 259-268.

31.Zhang C.B., Wang J., Qian B.Y., Li W.H. 2009. Effects of the invader Solidago canadensis on soil properties. Applied Soil Ecology, 43(2-3), 163-169.

32. www.gios.gov.pl/chemizm_gleb. 